\title{
Pendidikan Bercorak Sufisme dalam Pemikiran Abdul Munir Mulkhan
}

\author{
Sufism Patterned Education in the Thought of Abdul Munir Mulkhan \\ Mubarak Ahmad \\ $\bowtie$ Universitas Muhammadiyah Prof. DR. HAMKA \\ E-mail: mubarak@uhamka.ac.id $\bowtie$
}

Diterima: 10 November 2020 | Direvisi: 15 November 2020 | Diterbitkan: 16 November 2020

\section{ARTICLE INFO}

Keywords:

Sufism,

Tasawuf, Modernism.
Kata Kunci:

Sufisme,

Tasawuf,

Modernisme.

\section{ABSTRACT}

This study aims to explain and analyze Abdul Munir Mulkhan's sufism-style education thoughts in dealing with the problems of modern society. This thought is an exploration of ideas that aims to find a contemporary educational format that can overcome the pathologies of modernity and modernism. This study uses a historical method, with primary data derived from interviews with sources and secondary data from literature reviews of the works of other sources and writers with related themes. This research finds that the concept of education with Abdul Munir Mulkhan's sufism-style is an attempt to deconstruct theological doctrines in Islam and conventional sufism and direct them to the functionalization of Islam in social life. The epistemology of Sufism developed in Abdul Munir Mulkhan's sufism-style education aims to synthesize an objective-empirical paradigm with a subjective-intuitive nature so as to create an integrative paradigm model. Abdul Munir Mulkhan's sufism-style education ultimately aims to open people's internal awareness of situations, conditions, and spiritual responsibilities that can lead people to improve their self-quality and be responsive to the changes that occur around them, as well as to improve the welfare of other humans through the science of charity and the scientific charity.

Penelitian ini bertujuan untuk menjelaskan dan menganalisis pemikiran pendidikan bercorak sufisme Abdul Munir Mulkhan dalam menghadapi problematika masyarakat modern. Pemikiran tersebut merupakan eksplorasi pemikiran yang bertujuan mencari format pendidikan kontemporer yang dapat mengatasi patologi modernitas dan modernisme. Penelitian ini menggunakan metode historis, dengan data primer berasal dari hasil wawancara dengan narasumber serta data sekunder berasal dari telaah pustaka terhadap karyakarya narasumber dan penulis lainnya dengan tema yang terkait. Penelitian ini menemukan bahwa konsep pendidikan bercorak sufisme Abdul Munir Mulkhan merupakan upaya mendekonstruksi doktrin-doktrin teologis dalam Islam dan tasawuf konvensional dan mengarahkannya pada fungsionalisasi agama Islam dalam kehidupan sosial. Epistemologi tasawuf yang dikembangkan dalam pendidikan bercorak sufisme Abdul Munir Mulkhan bertujuan untuk menyintesis paradigma objektif-empiris dengan subjektifintuitif sehingga tercipta suatu model paradigma yang bersifat integratif. Pendidikan bercorak sufisme Abdul Munir Mulkhan pada akhirnya bertujuan untuk membuka kesadaran internal manusia terhadap situasi, kondisi, dan tanggungjawab spiritual yang dapat mengantarkan manusia ke arah perbaikan kualitas diri dan tanggap terhadap perubahan yang terjadi di sekitarnya, sekaligus dapat menyejahterakan manusia lainnya melalui ilmu amaliah dan amal yang ilmiah. 
Ahmad, 2020, Pendidikan Bercorak Sufisme ...

\section{PENDAHULUAN}

Masalah-masalah kemanusiaan kontemporer sebagai dampak dari pergaulan global yang cenderung materialistik serta sikap rigid keberagamaan kerap kali tampil dalam bentuk bencana lingkungan dan bencana kemanusiaan yang mengerikan. Sebut saja eksploitasi alam, kerusakan lingkungan, kriminalitas, disintegrasi, perang, dan berbagai bencana kemanusiaan lainnya kerap lahir akibat tindakan sengaja yang dilakukan oleh tangan-tangan manusia.

Para cerdik pandai di seluruh dunia mencermati bencana-bencana lingkungan dan kemanusiaan tersebut dan menengarai bahwa akar dari kerusakan-kerusakan tersebut berasal dari suatu cara pandang masyarakat modern terhadap bumi dan kehidupan yang berlangsung di atasnya. Pada perkembangan peradaban modern, para ilmuwan mencermati adanya sejenis "kanker" modernisasi yang memunculkan patologi untuk mengalienasi manusia dari alam dia tinggal. Patologi tersebut berupa cara pandang rasionalisme dan empirisme yang cenderung memposisikan alam sebagai alat (rasio instrumental) untuk menguasai dan menaklukkan alam (Hardiman, 1990).

Peradaban modern yang muncul di Eropa sekitar tahun $1.500 \mathrm{M}$ merupakan buah dari perlawanan masyarakat intelektual Eropa Abad Pertengahan terhadap segala bentuk pengekangan ideologis dan keilmuan yang otoritasnya dipegang oleh lembaga keagamaan. Bentuk perlawanan intelektual ini ditandai dengan hadirnya kesadaran baru, yaitu kesadaran subyektif, kritik, dan kemajuan. Maksud dari subjektif di sini adalah bahwa manusia mulai menyadari dirinya sebagai subjectum, yaitu sebagai pusat realitas yang menjadi ukuran segala sesuatu. Sedangkan yang dimaksud dengan kritik adalah kemampuan praktis rasio manusia untuk membebaskan individu dari wewenang tradisi atau untuk menghancurkan rasionalitasrasionalitas yang menyesatkan (pseudorationality). Hasil dari subjektivitas dan kritik tersebut pada gilirannya mengandaikan keyakinan akan kemajuan. Kemajuan diartikan sebagai kesadaran manusia akan waktu, karena waktu dianggap sebagai sumber langka yang tidak akan terulangi (Hardiman, 2004).

Imbas dari pemberontakan intelektual yang melahirkan zaman modern menghasilkan suatu paradigma baru tentang keilmuan yang bersifat sekuler. Paradigma keilmuan yang bersifat kesatuan (unity), holistik, dan totalitas -ciri pola pikir manusia Abad Pertengahan yang tampil dalam memahami metafisika dan fisika atas ordonansi gereja- dipukul mundur oleh independensi rasio manusia. Rasio independen inilah yang melatarbelakangi masyarakat modern untuk tidak melibatkan aspek-aspek metafisis (transendental) dalam tiap kegiatan keilmuan yang fisis (material). Berdasarkan prinsip rasional serta empiris, sikap hidup manusia akhirnya dipisahkan secara ekstrim antara yang objektif-empiris dengan yang subjektif-intuitif sehingga membuat ilmu menjadi sekuler.

Untuk mencegah bencana kemanusiaan akibat cara pandang manusia modern seperti yang dijelaskan di atas, perlu dikembangkan suatu gagasan untuk merujukkan kembali paradigma keilmuan yang tersekulerkan oleh modernisasi. Spesifik dalam konteks tradisi dan perkembangan keilmuan yang berkembang 
pada masyarakat Muslim, perlu dikembangkan suatu cara pandang integratif yang berupaya merujukkan paradigma modern yang bersifat patologis tersebut. Sektor strategis untuk mendorong paradigma integratif tersebut adalah lewat pendidikan.

Salah satu tokoh intelektual muslim Indonesia yang memiliki perhatian terhadap dampakdampak modernisasi pada masyarakat modern adalah Abdul Munir Mulkhan. Lewat karyakaryanya, Mulkhan kerap menghadirkan pemaknaan-pemaknaan kehidupan modern dengan menafsirkan kembali inti dari doktrin dan tradisi yang ada pada masyarakat Muslim. Mulkhan menengarai bahwa peradaban modern memiliki problem sejak ia dilahirkan. Problem peradaban modern bisa dilihat dari pola kehidupan manusia yang tersusun secara sistematik dalam suatu mekanisme perebutan peluang dalam alam fisik, ruang sosial, dan ruang ekonomi yang serba terbatas serta habisbagi. Imbasnya adalah terbentuk paradigma bahwa keberhasilan seseorang dalam segala aspek kehidupan hanya dapat dicapai jika manusia bisa menutup peluang sukses manusia lainnya atau jika orang lain gagal mendapatkan dan memelihara kesuksesannya.

Mulkhan menyatakan bahwa persaingan antar manusia semakin sengit di dalam ruang sosial dan alam yang semakin terbatas sebagai akibat dari deret-ukur pertumbuhan penduduk serta eksplorasi dan eksploitasi alam tak terbatas memanfaatkan jasa teknologi. Dengan iptek yang terus tumbuh semakin cepat, peradaban modern seperti sedang menciptakan alat penghancurnya sendiri ketika secara sadar manusia mengeksploitasi dirinya dan alam ini bagi kepentingan impersonal yang tak manusiawi (Mulkhan, 2005a).

Saat menelaah gagasan Mulkhan dalam upayanya mengatasi dampak buruk modernisme, terdapat nuansa pembahasan yang khas dibandingkan dengan karya-karya cendekiawan lainnya. Mulkhan adalah salah satu ilmuwan yang menelaah permasalahan manusia dan budaya masyarakat melalui konsep pendidikan bercorak sufisme. Hal ini menjadi unik dikarenakan pembahasan tasawuf Mulkhan nampak berbeda dengan konsep tasawuf yang populer (mainstream) dipahami oleh masyarakat muslim pada umumnya. HAMKA (1996) misalnya menyatakan bahwa arti dari tasawuf adalah membersihkan jiwa, mendidik, dan mempertinggi derajat budi. Tasawuf juga diartikan sebagai upaya menekan segala kelobaan dan kerakusan, memerangi syahwat yang terlebih dari keperluan untuk kesentosaan diri. Sedangkan, Nata (1995) berusaha memahami karakter sufi dari dua aspek, yaitu lahiriyah dan batiniyah. Menurutnya, karakter sufi dapat dipahami dengan menghubungkan orang yang menjalani tasawuf dengan orang-orang yang berada di serambi masjid dan bulu domba merupakan aspek tinjauan lahiriyah dari sufi. Karakter sufi seperti ini dianggap sebagai orang yang telah meninggalkan dunia dan hasrat jasmani, dan menggunakan benda-benda dunia ini hanya untuk memenuhi kebutuhan pokok seperti berpakaian dan makan untuk sekedar menghindarkan diri dari kepanasan, kedinginan, serta kelaparan. Kemudian karakter sufi lainnya melihat sufi sebagai orang yang mendapat 
Ahmad, 2020, Pendidikan Bercorak Sufisme ...

keistimewaan di hadapan Tuhan nampak lebih menitikberatkan pada aspek batiniyah.

Dari beberapa definisi di atas tampaknya hampir setiap definisi sufi dan tasawuf mengacu pada kondisi zuhud (asketik) dan tawadhu (sederhana). Sikap hidup kaum sufi dapat dikenali dengan ciri-ciri seperti menjauhkan diri dari keramaian dengan maksud membersihkan hati, memakai pakaian yang sederhana, dan senantiasa memperdalam penyelidikan tentang hubungan makhluk (manusia, hewan, tumbuhan, dan lain-lain) dengan Sang Khalik (Allah SWT). Namun demikian, konsep tasawuf yang ditawarkan oleh Mulkhan berbeda dengan konsep yang dijelaskan oleh HAMKA dan Nata.

Berdasarkan paparan di atas, perlunya dikaji argumen-argumen tasawuf Mulkhan dalam bentuk pendidikan bercorak sufisme dalam upayanya mengatasi dampak buruk modernisme pada masyarakat kontemporer. Tujuan dari kajian ini adalah mencari penjelasan dan menganalisis pemikiran pendidikan bercorak sufisme Abdul Munir Mulkhan dalam kaitannya dengan problematika masyarakat modern.

\section{METODE}

Penelitian ini dilakukan dengan metode historis dengan spesifikasi sejarah intelektual. Sebagai studi sejarah intelektual, penelaahan konsep dan ide dalam penelitian ini sangat ditekankan pada argumen-argumen yang diajukan oleh Abdul Munir Mulkhan. Penelitian ini menggunakan teknik baca dan teknik catat dalam pengumpulan datanya, sedangkan analisis yang dipakai adalah model interpretasi yang diarahkan pada penafsiran sejarah hidup (Andi, Riadi, \& Absor, 2020). Lebih detailnya, penelitian ini terdiri dari langkah-langkah sebagai berikut:

1) Heuristik

Dalam upaya pencarian dan pengumpulan data penelitian, peneliti berusaha melakukan wawancara terhadap Mulkhan terkait dengan permasalahan yang diangkat dalam tulisan ini. Di samping itu, peneliti juga mengumpulkan sumber-sumber yang berkaitan dengan pendidikan, tasawuf, dan karya-karya Mulkhan lainnya sesuai dengan topik yang dikaji (Gottschalk, 2008). Pengumpulan data dan sumber ditempuh melalui pendokumentasian hasil wawancara dan telaah pustaka (library research) pada karya-karya Mulkhan.

2) Kritik Sumber

Kritik sumber dilakukan untuk memverifikasi keabsahan sumber. Penelitian ini melakukan kritik sumber terhadap keaslian sumber (autentisitas) dan kesahihan sumber (kredibilitas) (Abdurahman \& Safa, 2007). Kedua metode kritik sumber ini dilakukan baik pada data primer maupun sekunder (Sevilla, 1993). Dalam perjalanan penelitian, autentisitas sumber yang diperoleh tidak mengalami kendala absurditas karena dibantu oleh wawancara dengan subjek penelitian (Abdul Munir Mulkhan). Sedangkan dalam pengujian kesahihan sumber, peneliti menemukan kemiripan filosofis karya cendekiawan lain dengan karya-karya Mulkhan, di antaranya konsep Kiri Islam Hasan Hanafi, konsep integrasi Islamic Studies dengan IImu Pengetahuan Umum M. Amin Abdullah dan Mulyadhi Kertanegara, konsep kearifan lokal sebagai solusi patologi modernitas Fritjof Capra, konsep aksi sosial 
profetik Kuntowijoyo, dan konsep-konsep liberalisasi dogmatis para pemikir liberal Timur Tengah seperti Abu Zayd, Abu el-Fadl, dan sebagainya. Namun, secara utuh karyakarya Mulkhan memiliki konsep-konsep yang khas dan sejauh analisis peneliti memiliki autentisitas tersendiri seperti karakteristik epistemologi sufismenya yang melibatkan analisis rasionalitas instrumental lazimnya pemikiran ilmu-ilmu sosial yang berkembang dalam tradisi filsafat kritis.

3) Teknik Interpretasi Sejarah

Pada penelitian ini, dilakukan dua pendekatan interpretasi, yaitu analisis dan sintesis. Kedua teknik ini dipandang sebagai metode utama di dalam interpretasi (Kuntowijoyo, 2005). Dalam proses interpretasi sejarah, peneliti berusaha mencapai pengertian faktor-faktor yang menyebabkan terjadinya peristiwa. Untuk mengetahui hal-hal yang melatarbelakangi pemikiran Mulkhan, model interpretasi diarahkan pada penafsiran sejarah hidup, pemaknaan terhadap modernitas dan modernisme, serta argumen-argumen pokok yang diajukan oleh Mulkhan terhadap konsep modernitas dan modernisme (Grondin, 2007).

4) Historiografi

Langkah terakhir yang dilakukan dalam penelitian ini adalah historiografi. Karena jenis penelitian yang dilakukan adalah historiografi sejarah intelektual, maka bentuk historiografinya bersifat tematik sesuai dengan isu yang ingin diuji lewat argumen Abdul Munir Mulkhan.

\section{HASIL DAN PEMBAHASAN}

Titik tolak argumen sufisme Mulkhan dapat dilihat pada upayanya menempatkan aspekaspek patologis dari tradisi ritualistik-spiritualis masyarakat modern dan sekularisme sebagai hal yang perlu diperbaiki. Oleh karena itu, tematema iman (keyakinan/kepercayaan), ibadah (ritus tindakan), dan akhlak (sikap/perilaku) masyarakat kontemporer yang identik dengan gaya hidup modern selalu hadir sebagai sasaran analisis dan kritiknya. Dari conditio sine qua non tersebut, Mulkhan bergerak menuju pendekatan humanis sebagai antitesisnya. Pendekatan humanis yang digunakan Mulkhan ditarik dari fungsi-fungsi profetik yang banyak mengandung nilai revolusioner, sehingga hal ini diharap mampu mendialogkan kultur religius masyarakat Indonesia yang mayoritas beragama Islam dengan realitas ketimpangan yang ada.

Setelah menemukan pola dialektis, Mulkhan menengarai tentang jalur alternatif sebagai landasan epistemologinya. Mulkhan menempatkan pendidikan sebagai wahana penyadaran kritis yang efektif untuk mensosialisasikan serta menanamkan counter hegemony terhadap budaya masyarakat modern sekaligus menempatkan kembali fungsi-fungsi agama sebagai pembebas ketertindasan manusia. Di sinilah kunci pokok epistemologi sufisme dalam spektrum intelektual Mulkhan. Mulkhan melakukan kajian mendalam Spiritual Quotient Danah Zohar dan lan Marshall tentang 'God Spot' yang secara esensi menurutnya tidak menyentuh wilayah transendental manusia. Mulkhan lalu melakukan peninjauan kembali terhadap epistemologi sufi yang berujung pada konsep kebenaran intuitif melalui ilmu hakikat 
Ahmad, 2020, Pendidikan Bercorak Sufisme ...

(makrifat) yang didapat melalui suatu proses (ikhtiyar) (Mulkhan, 2009).

Pendekatan ideologis yang taken for granted terhadap doktrin keagamaan dalam kaca mata Mulkhan akan sangat menghambat ekstrapolasi hakikat keilmuan dalam masyarakat muslim karena terkunci pada sikap fatalistik yang berlebihan. Di samping sikap fatalistik, metode pendidikan dalam model doktrinal seperti ini dapat memapankan status sosial antara santri dengan abangan, atau yang berilmu dengan yang bodoh dalam suatu hierarki tertutup sehingga tidak ada peluang untuk mereka agar berusaha memperbaiki dirinya dan bergerak leluasa menembus hierarki atas dasar kesadaran sebagai makhluk pembelajar yang bebas, terbuka, dan sadar akan eksistensinya. Konstruksi dasar pendidikan sufisme dalam pandangan Mulkhan mengacu pada manipulasi tindakan manusia melalui proses pendidikan yang bergulat dengan keadaan-keadaan objektif kehidupan (ikhtiyar).

Pendekatan intuitif yang senantiasa hadir dalam model epistemologi sufisme dielaborasikan dengan menafsirkan hudan (petunjuk) Tuhan dalam bentuk proses mencari (ikhtiyar) yang mencakup ketajaman analisis terhadap burhan (pengamatan, atau dalam paradigma keilmuan modern dikenal dengan observasi partisipan) dan bayan (ketajaman menganalisis teks atau nash sebagai referensi skripturalis dasar). Atas dasar ini, maka model pendidikan sufisme Mulkhan mengacu pada kekuatan membaca (iqra) petunjuk teks dan fenomena yang telah, sedang, dan akan terjadi. Jika dikaitkan dengan taksonomi Bloom tentang spesifikasi kognitif, afektif, dan psikomotorik, maka model pendidikan sufisme Mulkhan menguatkan bentuk pembelajarannya pada sisi kognitif yang kemudian dimanifestasikan dalam ketajaman afektif dan ketepatan tindakan pelaku (agency).

Kemudian, epistemologi sufisme Mulkhan mengarahkan indikator ketuntasan belajar dalam evaluasi portofolio dengan menangkap ketepatan akhlak (perilaku) manusia pendidikan ketika dibenturkan pada masalah-masalah yang dihadirkan. Instrumen studi kasus melalui kekuatan analisis dan pilihan tindakan yang diambil oleh manusia pembelajar mengambil asumsi dasar bahwa kesadaran mereka akan kehadiran Tuhan akan mengarahkan tiap tindakan dalam bingkai kearifan yang solutif, atau dalam Islam dikenal dengan rahmatan lil'alamiin (rahmat bagi seluruh alam).

Mulkhan menggunakan konsep sufisme untuk mendekonstruksi pola-pola pendidikan konvensional yang menurutnya habis-bagi karena terjebak pada kesadaran materialistik semata (Mulkhan, 2005a). Jebakan inilah yang ditengarai Mulkhan sebagai kegagalan ilmu-ilmu positif dalam menangkap pesan Tuhan yang akhirnya mengalienasi nilai-nilai kemanusiaan.

Untuk membebaskan manusia dari jebakan positivistik dan membuka jalan menuju kehendak sakral (mardhatillah), Mulkhan menawarkan suatu metode pembelajaran yang bercorak sufisme antroposentris (sufisme antroposentris mengasumsikan menyatunya manusia dengan kehidupannya sehari-hari; suatu konsep yang bertentangan dengan sufisme-teosentris yang mengasumsikan penyatuan wujud yang ilahi dengan yang insani, bukan dengan kehidupan sehari-hari).

Mulkhan mencermati perkembangan kurikulum dan materi keislaman dengan 
perkembangan ilmu pengetahuan kontemporer sebagai suatu alternatif strategis untuk melakukan perubahan besar dalam tatanan sosial masyarakat. Dalam menyikapi stagnasi Islamic studies dalam merespon perkembangan zaman, Mulkhan berpendapat bahwa jika di dalam wilayah sekuler dan profan manusia mempunyai mekanisme pemecahan konflik yang setidaknya bisa dilakukan melalui sistem-sistem politik yang lebih kurang demokratis. Dalam wilayah sakral ketuhanan dan ritual keagamaan bisa disebut tidak ada demokrasi karena kita belum mengenal pluralitas. Seluruh aspek keagamaan diletakkan di dalam perspektif kesempurnaan dan kemutlakan karena segala hal datang dari Tuhan yang Maha Tunggal dan Maha Sempurna. Sementara semua agama seperti dalam Islam dengan mudah menjadikan semua persoalan sebagai persoalan keagamaan dan ketuhanan yang sakral, yang tak mungkin dinegosiasikan (Mulkhan, 2005b).

Tampak bahwa Mulkhan mengkritisi terbelahnya Islamic studies dengan ilmu-ilmu pengetahuan umum sehingga menimbulkan kebingungan dalam menyusun solusi keilmuan yang tepat terhadap masalah-masalah kehidupan masyarakat yang terus berkembang. Mulkhan melihat bahwa penerapan rasionalitas material yang ad hoc dalam dunia sains (iptek) dan logika spiritual dalam dunia religi samasama tidak menunjukkan pemihakan terhadap realitas empiris.

Dalam melihat iptek modern (termasuk sistem ekonomi, politik, dan pendidikan), muncul permasalahan keilmuan yang mendasar. Masalah itu adalah ketika ilmu pengetahuan meletakkan kehidupan sosial sebagai produk mekanisme fisik-material. Jiwa dan akal pikiran manusia tidak diletakkan sebagai sebuah realitas unik, melainkan kepanjangan dari mekanisme fisis sehingga kepentingan dan kebutuhan hidup manusia terbatas hanya pada dimensi fisikmateriil berkaitan dengan kebutuhan makan, sandang, dan papan atau kebutuhan untuk berkuasa. Wilayah dan tugas ilmu hanya terbatas pada fungsi penjelasan, penganalisisan, dan pemaknaan atas fakta-fakta empiris yang bersifat materialistik dan berhenti pada relativitas dan probabilitas tanpa terkait pada fakta-fakta meta-empiris dan fakta-fakta universal yang berhubungan dengan struktur tertinggi piramida kebenaran dimensi metafisik, yaitu Tuhan.

Untuk menjelaskan permasalahan di atas, Mulkhan mengatakan:

Paradigma kesalehan ilmu sosial ialah fungsinya bagi jalinan rantai realitas kemanusiaan dan kealaman yang teologis. Pertama, tujuan universal kehendak Tuhan tentang rahmatan lil alamin dan tujuan kedua ialah jalinan rantai metafisik. Ukuran kebenaran tidak semata dilihat dari jumlah fakta dan pembawa berita (mutawatir) dan rantai tak terputus (sanad) tetapi kualitas pribadi dari setiap mata-rantai yang konsensual atau ijmai. Kebenaran relatif dan probabilistik yang tak pernah selesai diletakkan pada struktur metafisik. Dan, rasionalitas empirik diletakkan sebagai awal rasionalitas metafisik yang berhubungan dengan firman dan ayatayat qauliyah dan kauniyah. Inilah makna akhirat (masa depan teologis) lebih baik dari yang dekat atau kesementaraan duniawi (Mulkhan, 2005b).

Di sini Mulkhan berpendapat bahwa untuk dapat mengisi kekeringan spiritual keilmuan, maka secara generik segala sifat aksiologis ilmu harus dihadapkan dengan kehendak Tuhan yang rahmatan lil'alamin (rahmat bagi seluruh alam). Oleh karena itu, pandangan keilmuan yang 
Ahmad, 2020, Pendidikan Bercorak Sufisme ...

bebas nilai (value free) tertolak karena pada prinsipnya segala bentuk keilmuan selalu bersanding dengan kepentingan-kepentingan pragmatis.

Kemudian, untuk dapat mencapai jalinan rantai metafisik, segala bentuk relativitas ilmu harus disatukan dengan dunia metafisik. Dengan kata lain, realitas meta-empiris diwujudkan dengan pembacaan terhadap realitas empiris yang dalam paradigma sufistik disebut dengan wihdatul wujud (bersatunya wujud Tuhan dalam realitas empiris). Konsep ini dalam Islam dikenal dengan amanah dalam kehidupan sosial sehingga segala bentuk ilmu dapat difungsikan bagi tujuan-tujuan terjauh di luar dan yang bebas dari kepentingan personal. Dari sini doktrin sosial tentang amanah berfungsi bagi tujuan kolektif (sosial) dan vertikal (tauhid) yang bebas dari kepentingan personal dan faktual sehingga memiliki aspek rahmatan lil'alamin, yakni setiap tindakan sosial seseorang bisa menyumbangkan kerahmatan bagi orang lain sezaman atau pada zaman sesudah masa hidupnya yang disebut amal jariyah atau amal saleh (Mulkhan, 2005b). Ilmu-ilmu yang selama ini disebut sebagai ilmu umum ditempatkan ke dalam ilmu agama ataupun sebaliknya. Jika Islamic studies tetap dipakai, maka matematika, fisika, biologi, kimia, sosiologi, politik, psikologi, ekonomi, dan filsafat diletakkan di dalam satu tempat bersama ilmu kalam, tafsir, dan fikih.

Mulkhan juga menggagas epistemologi sufistik dalam kaitannya untuk mengantisipasi keterpurukan sisi kemanusiaan akibat modernitas. Bagi Mulkhan, cara, isi, dan tarekat sufistik terbukti mampu mengubah kepribadian dan kesadaran seseorang secara radikal dan revolusioner. Doktrin sufistik bisa dijadikan dasar etik pengembangan kehidupan lebih humanis dengan tetap memelihara produktivitas di tengah gaya hidup modern yang memproduksi ketidakadilan dan ketimpangan sosial (Mulkhan, 2007).

Mulkhan mengkaji pengembangan model pembelajaran sufi yang menempatkan maqamat sebagai tahap-tahap perkembangan kepribadian atau kecerdasan. Menurut Kartanegara, maqamat sufi adalah tahap-tahap perjalanan spiritual yang dengan gigih diusahakan oleh para sufi untuk memperolehnya. Perjalanan ini pada hakikatnya merupakan perjuangan spiritual yang panjang dan melelahkan untuk melawan hawa nafsu, termasuk ego manusia yang dipandang sebagai berhala besar (Kartanegara, 2006).

Melalui serangkaian zikir yang dilantunkan dalam hati dengan jumlah tertentu atau seperti sambil lalu dalam gerak nafas dan seluruh tubuh, nama dan sifat Tuhan hendak diaktualkan di dalam diri setiap pribadi ke mana sejarah diarahkan ke titik terjauh tempat Tuhan berada. Mulkhan menulis:
Seringkali dzikir itu dilantunkan secara jahar dalam serangkaian bunyi menciptakan sebuah musik ruhaniah yang ritmik dimana ruh manusia seperti mengenang kembali asal mula darimana ia datang. Dalam suasana itu penganut sufi seperti berada dalam keterlepasan dan keterbebasan ruhaniah dimana badan wadagnya tak lagi menjadi pembatas dan dunia fisik bukan sebuah keterikatan benda-benda, kepemilikan dan kekuasaan (Mulkhan, 2004).

Ucapan-ucapan dzikir, doa, dan kalimat tayyibah di dalam jumlah tertentu disertai gerakgerik fisik bagi sufi mempunyai implikasi spiritual di dalam suatu hubungan dengan tindakan sosial. Kaum sufi memandang bahwa melalui cara-cara seperti itu tujuan kebebasan dari 
belenggu materi dicapai dan kelepasan diperoleh. Dari aksi fisik tersebut seseorang mengalami dan bisa mencapai tahapan revolusioner kesadaran spiritual yang mencapai puncak pada sesuatu yang dikenal di dalam tradisi sufi sebagai makrifat.

Kebebasan dari belenggu materi bukan berarti menolak kelezatan duniawi. Materi duniawi dinikmati sebatas perlu dan dilakukan untuk tujuan spiritual hingga manusia mampu mengendalikan hasrat nafsu dalam keadaan sadar diri. Orientasi kesempurnaan hidup yang disebut insan kamil merupakan ruh dan etos dasar tindakan sufi, baik itu disadari atau berlangsung begitu saja telah menjadi bagian dari kehidupan umat manusia pada umumnya.

Struktur hubungan sufistik dalam dimensi spiritual di atas berhubungan dengan struktur hierarki realitas alam sebagai ciptaan Tuhan. Dalam sudut pandang sufisme, manusia bukan hanya bagian dari alam, namun juga sebagai puncak ciptaan yang memiliki kemampuan memahami subjek pencipta, yaitu Allah. Aktualisasi struktur puncak itu tergantung pada usaha manusia untuk memahami diri dan realitas alam sebagai penanda atau ayat-ayat Tuhan.

Kaum sufi melakukan berbagai usaha guna merealisasikan kualitas itu secara bertahap yang puncaknya disebut makrifat. Sebagai tahapan spiritual, makrifat mendasari kemampuan spiritual manusia sehingga dapat menjadi jalan untuk memperoleh pengetahuan akan realitas diri, alam, dan masyarakat. Di sini kemampuan makrifat dihubungkan dengan semua tahapan rohani sufi hingga posisi ittihad (kesatuan manusia dengan Tuhan) dan insan kamil (manusia sempurna).
Sementara itu, makrifat seringkali diberi arti sebagai suatu pengetahuan yang diperoleh lewat kerja akal yang bagi kaum sufi merupakan pemberian atau rahmat dari Allah berupa kemampuan mengetahui dan melihat Allah dari dekat tanpa perantara nama atau sifat-sifat Tuhan sendiri. Inilah yang oleh sufi dinyatakan bahwa penyebutan nama-nama dan sifat-sifat Tuhan memberi petunjuk belum sempurnanya ilmu yang bersangkutan, karena nama dan sifat Tuhan bukanlah zat-Nya sendiri. Pandangan yang dikemukakan oleh para penganut tarekat sufi ini menyadari bahwa penyebutan nama dan sifat Tuhan belum mengantarkan kedekatan manusia pada-Nya karena orang yang dekat sesuatu tak perlu menyebut nama dan sifat sesuatu (Rakhmat, 1999).

Dalam sudut pandang sufistik, makrifat berarti hilangnya jarak atau penghalang antara yang melihat dan yang dilihat, antara yang mengetahui dan yang diketahui atau subjek dan objek pengetahuan. Maqam (kedudukan) itu juga berarti pencairan segala batas fisik yang melampaui sekat-sekat sehingga yang nampak kemudian adalah hakikat dari obyek itu sendiri. Makrifat merupakan jalan dan keadaan ketika seseorang berada dalam kemampuan melihat tanpa batas formalitas dan tanpa simbolitas. Pengertian ini terutama dipakai berkaitan dengan konsep manusia sempurna atau insan kamil yang dalam fungsi sederhana berarti kemampuan melihat inti segala obyek. Menurut Kartanegara (2006), pengetahuan makrifat hanya dapat tercapai lewat pengalaman (harus dialami).

Pencapaian makrifat di atas berkaitan dengan ide penciptaan manusia dan alam, atau dalam 
Ahmad, 2020, Pendidikan Bercorak Sufisme ...

filsafat dikenal dengan teori emanasi atau nadlariatul faidh. Al-Farabi (Abu Nasr Muhammad al-Farabi, 870-950 M) berpendapat bahwa penciptaan alam maujud (juga manusia) ini berasal dari Tuhan melalui proses emanasi, alam maujud tersebut muncul ketika Tuhan sebagai Yang Pertama memikirkan dirinya sendiri (Fakhry, 1986).

Sufisme seringkali dikaitkan dengan ajaran tentang proses mencapai suatu tingkat kesempurnaan hidup yang disebut makrifat atau insan kamil yang bisa dicapai seseorang dengan usaha keras. Usaha ini dilakukan dengan praktik tentang penyucian diri dengan ibadah, menjauhkan diri dari kemewahan duniawi yang disebut zuhud guna mencapai kebahagiaan dan keselamatan abadi guna mencapai makrifat dan insan kamil tersebut.

Di situ pula makna ajaran tentang hulul, yaitu keadaan yang dicapai sufi ketika terjadi kesatuan aspek kemanusiaan (an-Nasut) dan ketuhanan (al-Lahut), yaitu saat Tuhan memilih tubuh-tubuh manusia tertentu untuk mengambil tempat di dalamnya, setelah sifat-sifat kemanusiaan dalam tubuh dihilangkan. Keadaan ini disebut tahalluq, yaitu ketika kemanusiaan seseorang melebur ke dalam akhlak Tuhan, atau berakhlak dengan akhlak Tuhan. Ittihad atau hulul ialah pencapaian sufi saat bersatu dengan Tuhan, ketika manusia yang mencintai dan Tuhan yang dicintai menjadi satu wujud walaupun faktanya berpisah.

Pencapaian keadaan ittihad atau hulul tersebut di atas dilakukan dengan cara yang disebut tarekat, yaitu metode perjalanan seorang sufi menuju Tuhan dengan cara menyucikan diri dengan bimbingan seorang syekh atau mursyid (guru). Untuk itu seorang sufi harus mengikuti petunjuk guru berakhlak seperti akhlak rasul dan selalu bertindak baik atau beramal menurut syariah. Di sini pula seorang sufi harus bersikap qana'ah sebagai bagian dari zuhud yaitu merasa cukup dengan sesuatu yang telah dimiliki atau sering diartikan meninggalkan dunia dan jauh dari kehidupan materi.

Istilah lain pencapaian sufi melalui tarekat disebut dengan kasyaf sebagai suatu tingkatan tertinggi dalam tasawuf, yaitu suatu keadaan terbukanya tabir atau dinding rahasia nurani dan Tuhan karena dekat pada Tuhan. Keadaan ini juga sering disebut musyahadah, yaitu pengalaman mistik manusia yang langsung bisa menyaksikan secara langsung suatu hal. Untuk itu seorang sufi perlu melakukan aktualisasi kefakiran, yaitu suatu keadaan kemiskinan dari kepuasan rohaniah sehingga tidak mempunyai nafsu menguasai harta dan tidak meminta dari sesuatu yang telah ada. Inilah yang sering disebut dengan darwis. Tindakan seperti ini juga banyak dikaitkan dengan sikap tawakal, yaitu penyerahan diri secara total hanya kepada Tuhan. Demikian pula dengan sikap ikhlas, yaitu melakukan perbuatan semata-mata mengharap ridha (perkenan) Allah.

Untuk dapat memurnikan dirinya, seorang sufi harus melakukan mujahadah (berjuang melawan hawa nafsu dan menundukkan hawa nafsu untuk maksud zuhud). Tindakan ini disebut takhalli, yaitu mengosongkan diri dari sikap ketergantungan hidup duniawi yang berarti sikap mawas diri atau menghindarkan diri dari perbuatan dosa. Kaum sufi mencapai posisi atau keadaan tersebut melalui riyadlah, yaitu latihan kerohanian dengan menjalankan ibadah dan menundukkan nafsu syahwat.

Perkara menahan nafsu seperti di atas dilakukan kaum sufi dengan sikap rida atau rela, 
yaitu menerima segala ketentuan dari Tuhan dengan segala kesenangan hati. Selanjutnya dengan sikap sabar, yaitu konsisten dengan tetap melaksanakan semua perintah Tuhan dan menjauhi larangan-Nya, tahan uji menghadapi cobaan. Banyak tindakan yang dilakukan berkaitan dengan sikap tersebut seperti tobat, yaitu tidak lagi membuat dosa dan melupakan segala hal kecuali Tuhan; dan sikap warak yaitu meninggalkan segala makanan atau tindakan yang diragukan kehalalannya.

Pengalaman memperoleh perubahan kesadaran secara radikal dan revolusioner kaum sufi ini jika dapat diterapkan dalam sikap hidup sehari-hari dapat mengubah sudut pandang rasionalitas instrumentalis yang bergerak atas kesadaran pragmatis-materiel menuju humanisme-transendental. Kemudian karena sifatnya yang lebih populis dan terbuka bagi semua orang, ajaran sufisme dapat dilakukan oleh siapa saja, baik dari kalangan masyarakat awam, ulama, golongan berpendidikan tinggi dan kaya, atau rakyat yang tak pernah bersekolah.

Siapa pun bisa menempatkan diri di dalam satu titik dari lingkaran mata rantai kegaiban yang membuatnya seperti tersedot tanpa sadar ke dalam arus gelombang rohaniah amat dahsyat yang mengasyikkan dan memabukkan. Sufi teoretis, tarekat atau praksis sufi merupakan gejala kehidupan muslim santri atau abangan, kelas atas atau wong cilik. Gejala sosial masyarakat sufi telah lama menarik perhatian ahli ilmu sosial saat ajaran sufi begitu populer bagi orang kebanyakan. Kunci keberagamaan sufi atau pun syariah serta model lain samasama terpusat pada usaha memperoleh keridaan Tuhan melalui takdir-Nya dengan tata laku yang bisa beragam dan berbeda di sanasini.

Kemahakuasaan Tuhan dan takdir-Nya sebagai rahasia abadi selalu membuka peluang bagi siapa saja untuk memperoleh keridaan Tuhan dengan caranya sendiri. Dari keadaan ini, maka muncul beragam teknik penyucian jiwa yang dengan harapan memperoleh keridaan Tuhan sehingga semua menjadi mudah bahkan serba boleh karena Tuhan telah menyatu dalam dirinya.

Jika manusia bersedia bebas jebakan kepentingan sesaat dan personal dengan memasuki kemanusiaan universal dan kepentingan transenden serta ilahiah, akan selalu ada harapan kehidupan penuh rahmah dan cinta kasih. Menurut Mulkhan:

Kesatuan mistis terhadap alam dan ketuhanan atau apa yang dipercayai sebagai Tuhan yang mengatur kehidupan manusia dan keseluruhan alam tersebut adalah dasar fundamental sikap hidup dan perilaku sosial-politik. Dari sini seseorang bisa dan bersedia menempatkan diri di atas semua kepentingan materiil kemanusiaan. Seseorang dengan keyakinan mistis itu berpeluang besar mengembangkan cinta kasih atas sesama di luar batas-batas formal kepemelukan agama dan batas-batas kesukuan dan kebangsaan (Mulkhan, 2007).

Jika potensi ajaran sufi ini mengarahkan pada sikap cinta kasih dan kebajikan, maka paradigma kesejukan dalam agama sudah pasti tidak akan mencederai hak-hak dasar kemanusiaan. Dalam hubungan itulah penting untuk direnungkan kembali dimensi moral kehidupan yang memberi ruang bagi seluruh lapisan masyarakat. Inilah moral ke-Tuhanan yang bebas kepentingan politik sehingga surga menjadi harapan mereka 
Ahmad, 2020, Pendidikan Bercorak Sufisme ...

yang tertindas. Masa depan sejarah tidak semakin menjauhkan peran rakyat dalam dinamika keagamaan surgawi dan nasionalitas bangsa.

Dalam perkembangan zaman dewasa ini, visi kemanusiaan keagamaan mengalami kesulitan saat peradaban industri-lanjut mengarah pada materialisasi spiritualitas bagi kebutuhan ekonomi materialis yang dalam hal ini komunitas agama terperangkap di dalamnya. Kehausan spiritual masyarakat industrial mendorong rekayasa spiritual dalam kerangka industrialisasi. Gejala ini tampak dalam penggunaan simbolsimbol keagamaan dalam dinamika politik dan ekonomi sehingga rekayasa spiritual masyarakat modern lebih menonjol dalam praktik gaya hidup (life style). Agama pun mengalami materialisasi yang dengan 'terpaksa' ditempatkan sebagai bagian dari dinamika pembangunan materiel dan industrialisasi. Bersamaan dengan itu, pemikiran dan pengembangan kesadaran keagamaan yang asli, parenial, dan sufistis seperti terabaikan dan dibiarkan berada di luar dinamika pembangunan dan industrialisasi.

Materialisasi spiritual akhirnya merupakan resiko sosial akibat penggunaan simbol keagamaan bagi tujuan non-agama yang terlepas dari dimensi kemanusiaan atau sebaliknya. Di sisi lain pemikiran keagamaan kurang atau tidak menyentuh gerak dinamis peradaban modern industrial di saat peradaban penuh kesengajaan meminggirkan wilayah metafisis keagamaan. Di tengah pergumulan kemanusiaan dan peradaban industrial demikian itulah, proses ibadah dan komitmen ideologis terhadap doktrin keagamaan perlu dijadikan momentum pencerahan keagamaan yang lebih sufistis. Doktrin sufi menjadi strategis untuk mengembangkan visi kemanusiaan dan keagamaan industrial melalui kritik tradisi, kesadaran keagamaan, dan intelektualisme peradaban modern.

Karena itu perlu dikembangkan kesadaran keagamaan baru yang lebih sufistis sebagai antitesis dari keagamaan legal-formal bersama pengembangan kesadaran peradaban sintesis dan mistis antara peradaban materiel dan spiritual sebagai bagian integral kesadaran kemanusiaan industrial. Beragama, berarti komitmen kemanusiaan yang pluralistis dan menjadi modern berarti mempertinggi kesalehan, serta sebaliknya. Visi keagamaan, kemanusiaan, dan peradaban industrial memerlukan kesadaran historis atas pluralitas kebenaran "keagamaan". Pencerahan kesadaran keagamaan dan modernitas di atas merupakan tantangan dan agenda besar pengembangan pemikiran dan dakwah melalui pendidikan yang membebaskan karena meniscayakan tanggung jawab moral dan politik elite agama. Inilah kesalehan industrial saat teknologi menjadi wujud kesalehan berfungsi sosial. Dalam bentuk seperti ini, wajah Tuhan dalam kehidupan duniawi akan dapat memberi ruang semua orang untuk mengembangkan keasadaran keagamaan, kemanusiaan, dan kehidupan.

Pembangunan model pendidikan liberal yang didasarkan pada epistemologi sufistik merupakan proyek kemanusiaan dalam doktrin Islam yang menyatukan seluruh lapisan sosial untuk bersama menang dalam pergulatan hidup. Persoalannya ialah kesediaan berbagi surga bagi semua dan memberi sebagian kekuasaan politik dan harta benda bagi orang lain di tengah perangkap teknologi ekonomi materialis. Karena itu, Islam harus dipahami sebagai agama 
universal bagi kemanusiaan dalam kehidupan sosial yang terus berubah dan berkembang, dan model pembelajaran yang selama ini hadir harus diorientasikan pada praktik pembebasan seluruh umat manusia. Islam diwahyukan bukan bagi kepentingan Tuhan sendiri atau hanya bagi kepentingan umat Islam, tapi penebaran rahmatNya bagi seluruh umat manusia.

Jika model pendidikan liberal yang membebaskan dielaborasikan melalui praktik pemberantasan penindasan dengan kesadaran makrifat sufisme ini diterapkan, maka bentuk sifat-sifat materialistik akan dapat menjangkau wilayah meta-empiris sehingga kesadaran berTuhan (ketika manusia memahami hakikat penciptaannya) dapat termanifestasikan dalam kehidupan yang interdependen dengan kondisi sekitarnya. Kondisi ini dirasakan oleh Mulkhan dapat menjawab tantangan fungsionalitas agama sekaligus mampu mengembangkan keilmuan modern menjadi lebih arif ketika berhadapan dengan realitas sosial.

\section{KESIMPULAN}

Argumen pendidikan bercorak sufisme yang digagas oleh Abdul Munir Mulkhan merupakan suatu bentuk pemikiran integratif yang ingin mengatasi kesadaran dan pola interaksi antarmanusia dalam masyarakat modern yang cenderung kaku (rigid), subjektif, dan egosentris. Oleh karena itu, Mulkhan menengarai bahwa keterputusan keilmuan manusia yang memisahkan ranah transendental dengan imanen harus dipertautkan kembali melalui metodologi sintesis yang terbentuk dengan menafsirkan kembali hudan (petunjuk) Tuhan. Untuk dapat mempertautkan kembali kesenjangan antara keilmuan modern dengan realitas absolut (transendental), maka Mulkhan melakukan kritik terhadap doktrin-doktrin keagamaan yang menurutnya secara universal memiliki keterkaitan fungsi untuk manusia. Model kritik yang dilakukan Mulkhan adalah dengan mendekonstruksi argumentasi fikih yang cenderung dipahami secara ideologis oleh masyarakat pada umumnya, dan merangkainya dalam konsep pendidikan bercorak sufisme.

Model pendidikan bercorak sufisme yang ditawarkan oleh Mulkhan mengarah pada liberalisasi doktrin dan fungsionalisasi praksis yang terimplementasi dalam sufismeantroposentris. Pendidikan bercorak sufisme menurut Mulkhan adalah sebuah praksis kesadaran teologis dan ilmiah sehingga memiliki nilai ibadah dan salah satu jalan mencari Tuhan, di samping memiliki sisi argumentatif dan logis. Dalam doktrin Islam, praksis pembebasan seseorang atau sekelompok orang dari derita kemiskinan, kebodohan, dan ancaman ketertindasan serta perlakuan tidak adil merupakan salah satu tujuan ajarannya yang bersifat membebaskan. Dengan sifatnya yang praksis, maka pendidikan bercorak sufisme dalam pemikiran Mulkhan mengharuskan perubahan paradigma dari ritus menjadi aksi. Oleh karena itu, aksi-aksi yang dibangun harus melibatkan kesadaran akan perjuangan (jihad) di jalan Allah ( fi sabilillah).

Konsep pendidikan bercorak sufisme Mulkhan memulai proyeknya dari upaya menafsir ulang doktrin-doktrin keagamaan agar memiliki relevansi secara fungsional, khususnya penafsiran ulang terhadap doktrin yang menyebabkan manusia mencondongkan dirinya 
ke arah sikap ekslusif umat-umat beragama, kesalehan statis (fatalistik), dan kapitalisasi amal saleh yang tampak sebagai problem keadilan dan kesejahteraan sosial. Mulkhan mengajukan fokus ontologis, epistemologis, dan aksiologis ilmu harus dihadapkan pada kehendak Tuhan yang rahmatan lil'alamin (rahmat bagi seluruh alam), oleh karena itu maka tujuan akhir segala bentuk ilmu adalah metafisika. Pendidikan bercorak sufisme Mulkhan memaknai amanat kitab suci Al-Qur'an yang mengarahkan manusia pada fungsi kolektif (sosial) dan fungsi vertikal (tauhid) dalam bingkai rahmatan lil'alamin. Setiap tindakan seseorang diarahkan pada hadirnya kerahmatan bagi orang lain dalam bentuk amal jariyah atau amal saleh.

Struktur hubungan pendidikan bercorak sufisme dengan modernitas dan modernisme adalah memaknai manusia bukan hanya sebagai bagian partikular dari alam, melainkan sebagai puncak ciptaan yang memiliki kemampuan memahami subjek pencipta, yaitu Allah. Akhirnya, konsep pendidikan bercorak sufisme menurut Mulkhan mengarahkan manusia pada sikap cinta kasih dan kebajikan, sehingga paradigma biofilia dalam hidup tidak menghendaki kerusakan pada manusia dan isi bumi lainnya.

\section{DAFTAR PUSTAKA}

Abdurahman, D., \& Safa, A. (2007). Metodologi penelitian sejarah. Ar-Ruzz Media.

Andi, A., Riadi, S., \& Absor, N. F. (2020). Perilaku Altruistik dan Eklektik dalam Praksis Pendidikan Kiai Ahmad Dahlan. JURNAL YAQZHAN: Analisis Filsafat, Agama Dan Kemanusiaan, 6(1), 1-15.

Fakhry, M. (1986). Sejarah Filsafat Islam, terj. Jakarta: Pustaka Jaya.

Gottschalk, L. (2008). Mengerti Sejarah. Jakarta:
Ul-Press.

Grondin, J. (2007). Sejarah Hermeneutik: Dari Plato Sampai Gadamer, terj. Yogyakarta: Ar-Ruzz.

HAMKA. (1996). Tasauf Modern. Jakarta: Pustaka Panjimas.

Hardiman, F. B. (1990). Kritik ideologi: pertautan pengetahuan dan kepentingan. In Pustaka Filsafat. Yogyakarta: Kanisius.

Hardiman, F. B. (2004). Filsafat modern: dari Machiavelli sampai Nietzsche. Jakarta: Gramedia Pustaka Utama.

Kartanegara, M. (2006). Menyelami lubuk tasawuf. Jakarta: Erlangga.

Kuntowijoyo. (2005). Pengantar IImu Sejarah. Jakarta: Bentang Pustaka.

Mulkhan, A. M. (2004). Kecerdasan Ma'rifat dan Revolusi Spiritual dalam Tradisi Sufi". Jurnal Pendidikan Islam, 2(1).

Mulkhan, A. M. (2005a). Kecerdasan Makrifat (Ma'rifat Quotient), Jalan Pembebasan Manusia Dari Mekanisme Konflik. In P. U. Tanthowi (Ed.), Begawan Muhammadiyah, Bunga Rampai Pidato Pengukuhan Guru Besar Tokoh Muhammadiyah. Jakarta: PSAP.

Mulkhan, A. M. (2005b). Kesalehan multikultural: ber-Islam secara autentikkontekstual di aras peradaban global. Jakarta: PSAP.

Mulkhan, A. M. (2007). Sufi pinggiran: menembus batas-batas. Yogyakarta: Impulse : Kanisius.

Mulkhan, A. M. (2009). Wawacara dengan Abdul Munir Mulkhan. Yogyakarta.

Nata, A. (1995). Ilmu Kalam, Filsafat, dan Tasawuf (Dirasah Islamiyah IV). Jakarta: Rajawali Pers.

Rakhmat, J. (1999). Meraih cinta Ilahi: pencerahan sufistik. Jakarta: Remaja Rosdakarya.

Sevilla, C. G. (1993). Pengantar Metode Penelitian. Jakarta: UI Press. 